
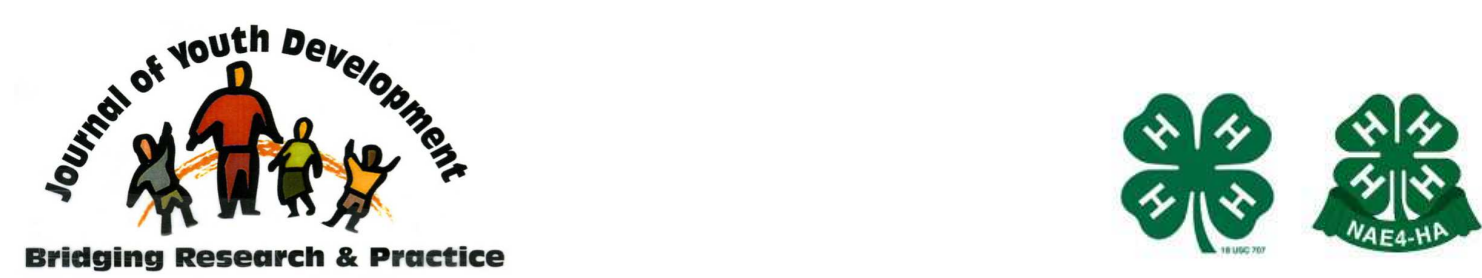

\title{
4-H Afterschool - Making an Impact
}

\author{
JoLene Bunnell \\ Associate Professor \\ Utah State University Extension, Utah County 4-H \\ Provo, UT \\ joleneb@ext.usu.edu \\ Robert Pate \\ Assistant Professor \\ Utah State University Extension, Weber County 4-H \\ Ogden, UT \\ rpate@ext.usu.edu
}




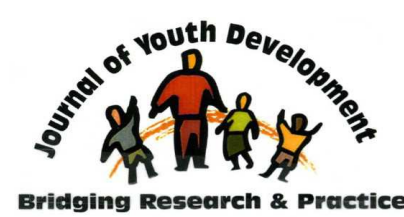

Volume 1, Number 1, Spring 2006
JOURNAL OF YOUTH DEVELOPMENT

bridging research and practice

\title{
4-H Afterschool - Making an Impact
}

\author{
JoLene Bunnell and Robert Pate \\ Utah State University Extension
}

\begin{abstract}
H Afterschool is making a positive impact on youth, families, and their communities. Utah State University Extension has implemented a 4-H Afterschool club at four elementary schools in lowincome neighborhoods. At each of the sites, 4-H offers sixteen different project clubs. Survey results indicate that the 4-H Afterschool program is building positive social skills in the youth, providing positive alternatives to idleness and antisocial behavior, and supporting parents in the primary role of care giving. The Afterschool clubs incorporate project activities, a service learning component, and a final showcase for the parents. Youth development professionals, using the experiential learning model of $4-\mathrm{H}$, can affect positive change within their communities by implementing a 4-H Afterschool program.
\end{abstract}

\section{Introduction}

In the United States, $69 \%$ of two-parent families and $71 \%$ of single-parent families with young children report that their work schedules leave their children in need of supervision during the before/after school hours (U.S. Bureau of Labor Statistics, 2000). Forty-four percent of parents do not provide any form of supervision during these hours (National Center for Educational Statistics, 1997). It is estimated that as many as seven to 15 million school age children leave school for an empty home on any given day of the week (U.S. Department of Education, 2000). Furthermore, up to 15 million American youth do not participate in structured education or recreational activities during after-school hours (U.S. Census Bureau, 2000). This leaves children in self-care, which has been associated with negative social and academic outcomes (Coolson, Seligson\& Garbarino, 1985). 
Studies have found that youth with nothing to do after school are more susceptible to violent juvenile crime, substance abuse, antisocial behavior, poor academic performance and dropping out of school (Chung, A., 2000). 4-H Afterschool is addressing this problem by providing youth with opportunities to have fun while developing lifelong skills through experiential learning in a safe, healthy, enriching environment. Children that participate in quality after-school programs, have positive benefits in their social and academic development (Junge, Johns, George, Conklin-Ginop, \& Valdez, 2000).

\section{Purpose of Program}

Utah State University Extension conducted a three-year statewide Accountability in Action survey and held town meetings in order to receive input from our clientele and provide direction for future planning of extension programs. Results from the extension sessions found providing productive outof-school activities was one of the greatest needs for local clientele (Holmes, 2003).

With so many children spending their after-school time unsupervised, the need for quality after-school programming is great. Utilizing 4-H's expertise in youth development, the 4-H Afterschool Initiative has been established to start, strengthen, and enhance quality after-school programs nationwide. These programs can provide a safe place for youth to go after school, give them additional learning opportunities, and help keep them out of trouble by involving them in constructive activities.

The main goals of the 4-H Afterschool program are:

- Improve social outcomes of participating youth by focusing on improving academic success and building life skills. Life skills include community service, character building, teamwork, decision-making, self esteem, etc. as identified in the targeted life skills model (Hendricks, 1998).

- Provide positive and productive alternatives to idleness and antisocial behavior. 4-H Afterschool clubs focus on a variety of enrichment activities such as computers, theater arts, dance, arts and crafts, etc.

- Support parents in their primary care giving role by providing a safe location for youth during otherwise unsupervised out-of-school time.

\section{Activities Involved}

The basic structure of the program includes:

- One part-time 4-H Afterschool coordinator that partners with the principal in running the dayto-day operation of the program. The coordinator recruits and trains the volunteer leaders and provides overall supervision and structure to the program.

- Each school offers eight different clubs per semester for a total of sixteen clubs per year.

- Each club leader is given a $\$ 300$ stipend for running the club. To receive the stipend, they must complete the following requirements:

- Conduct a minimum of ten club meetings, one service learning activity and one final parent showcase each semester.

- Meet for one to one-and-a-half hours each time.

- Keep attendance records of weekly meetings. 
- Have each parent complete the parent survey.

- Have each youth (3rd grade and older) complete the youth development survey.

- $\quad$ Complete a club leader evaluation.

- Turn in electronic photos of club meetings and activities.

4-H Afterschool clubs are typically offered after school each day, Monday through Thursday. A variety of enrichment-type 4-H Afterschool clubs identified by parents and students as high interest are offered. Club choices include: theater arts, dance, public speaking, arts and crafts, sports and fitness, and computer technology.

Each club can accommodate up to fifteen youth and still maintain an appropriate adult/youth ratio. Previous research shows that children attending after school programs with smaller student to teacher ratios report more skill attainment than children enrolled in programs with higher student to teacher ratios (Baker \& Witt, 1996). Clubs are generally divided into age groups to ensure club activities are on an age-appropriate level. Using the club structure of $4-\mathrm{H}$, leaders can build academic skills while youth are having fun. Cooperative learning has enhanced social and academic development in children (Johnson \& Johnson, 2003). The basic design of 4-H Afterschool clubs provides an excellent model for preventing problem behaviors and promotes socially responsible decision-making.

The 4-H philosophy is "learn by doing" which is the most effective way for young people to learn new skills (Deen, Bailey, \& Parker, 2001). In the challenging and stimulating environment of a 4-H Afterschool club, youth are exposed to new ideas and opportunities, given responsibilities, and most importantly, have an opportunity to practice what they are learning. This hands-on approach leads to increased self-awareness and self-esteem, and increases achievement in content areas.

\section{Target Audience}

The target audience for the Utah 4-H Afterschool program is elementary age youth from Kindergarten through the sixth grade. In this study there were a total of 489 youth enrolled in four elementary schools for the 2004-2005 school year. The schools where selected from lower income neighborhoods. According to a study conducted by Junge, Manglallan, and Raskauskas, (2003) youth in Kindergarten through second grade scored lower on all individual life skill questions than students in the upper grades due to developmental abilities at various ages. For this reason, the study focused on third through sixth grades where self-report of skills is more appropriate.

\section{Challenges of Establishing Afterschool Programming}

One of the challenges of afterschool programming is acquiring adequate funds to implement the program. Funding is needed to hire a part-time coordinator for each school, stipends for the club leaders, club materials and supplies, nutritious snacks for the students, awards and recognition for the youth, and for leader/staff training. By diversifying funding sources, these programs can be sustained from year to year. Utah State University Extension has supported the Afterschool program with funding from the following sources:

- Department of Workforce Services - Office of Child Care

- Department of Education - Safe and Drug Free Schools

- Division of Substance Abuse Prevention and Mental Health 
- Department of Education - Gifted and Talented

- 21st Century Community Learning Centers

- Minimal enrollment fee for club members to participate

Agencies may consider funding from private foundations, through higher enrollment fees or material and supply donations from local businesses.

Afterschool programming is challenged with a high turnover rate due to the low wages often provided for qualified staff. Utah State University has helped solve this problem by only hiring a part-time coordinator for each school, and rewarding volunteer leaders with a $\$ 300$ stipend upon completion of the ten-week club. This reduces the expense that would be incurred by the hiring process. The stipend provides an incentive for the volunteer to be present every week, to complete the required data collection, and attend the required training.

A final challenge in the afterschool programming is the overwhelming demand from the families at the four targeted school. There are more youth wanting to enroll in the clubs than can be accommodated and still maintain the 15 to 1 child/adult ratio. Almost every club fills to capacity (with a substantial waiting list) within minutes on enrollment day.

Despite the challenges described, the obstacles are minimal when compared to the positive outcomes the families, youth, and communities receive by participating in programs such as 4-H Afterschool.

As Youth Development Professionals we can develop life skills in the youth we serve, provide positive alternatives to idleness and antisocial behavior, and support parents in their primary care giving role by offering opportunities such as 4-H Afterschool Clubs.

\section{Survey Results}

Surveys were completed by 506 youth. This number was larger than the number enrolled due to youth participating in multiple clubs. Of the 412 different households/parents involved in the program, 287 (69.7\%) parents completed the survey.

\section{Adult Responses:}

Results of the parent respondents, indicating they "agreed" or "strongly agreed" ( $\mathrm{N}=287)$ found:

99\% indicated that the 4-H Afterschool club is a place where their child learns new skills and interests.

98\% said their children like coming and enjoy their Afterschool 4-H clubs.

$98 \%$ would recommend the program to other parents.

$99 \%$ appreciated the 4-H Afterschool club being a safe place for their child to be during unsupervised hours after school.

$97 \%$ felt their child gained more confidence because of their 4-H Afterschool experience.

\section{Youth Responses:}

Results of the youth survey $(\mathrm{N}=506)$ indicated:

$94 \%$ said they learned new skills.

93\% felt they developed more confidence while involved in 4-H Afterschool. 
$97 \%$ are comfortable at 4-H Afterschool.

93\% indicated that 4-H Afterschool helped them have a more positive attitude.

$96 \%$ feel more positively about themselves as a result of their $4-\mathrm{H}$ Afterschool club.

\section{Program Success}

Based on the responses given, the 4-H Afterschool program was successful in meeting the program's three main goals:

- Improve social outcomes of participating youth.

- Provide positive alternatives to idleness and antisocial behavior.

- Support parents in their primary care giving role.

\section{Implications for Youth Development Professionals}

Conducting activities similar to those provided through 4-H Afterschool clubs is a viable means for youth development professionals to impact youth and families in their communities. Youth need opportunities to have fun while developing lifelong skills through experiential learning in a safe, healthy, enriching environment. Programs based on the 4-H Afterschool club design can be modified by any youth serving agency to meet critical needs for rural, suburban, and urban communities and families.

\section{References}

Baker, D., \& Witt, P.A. (1996). Evaluation of the impact of two after-school recreation programs. Journal of Park and Recreation Administration. 14(3), 23-44.

Chung, A. (2000). After-school programs: Keeping children safe and smart. Washington, D. C.: U.S. Department of Education.

Coolsen, P., Seligson, M., \& Garbarino, J. (1985). When school is out and nobody is home. Chicago: National Committee of Prevention of Child Abuse.

Deen, M.Y., Bailey, S.J. \& Parker, I. (2001).Life skills evaluation system. Wenatchee, WA: Washington State University Cooperative Extension.

Hendricks, P.A. (1998). Targeted life skills (TLS) model. Ames, IA: Iowa State University Extension.

Holmes, D. (2003). Accountability in Action Executive Summary Combined Years 2001, 2000 and 2003. Utah State University Extension.

Johnson, D.W, \& Johnson, R.T. (2003). Joining together: Group theory and group skills. New York: A and B Publishing.

Junge, S.K., Manglallan,S., \& Raskauskas, J. (2003). Building life skills through afterschool participation in experiential and cooperative learning. Child Study Journal 33(3), 165-174. 
Junge, S.K., Johns, P.A., George, J.L., Conklin-Ginop, E., Valdez, I.X. (2000). The effects of schoolage child care in northern California on parent's stress and job productivity. In M.T. Braverman, R.M. Carlos, \& S.M. Stanley (Eds.), Advances in youth development programming (pp. 47-60). Oakland, CA: UC Agriculture \& National Resources Cooperative Extension.

National Center for Education Statistics. (1997). Schools serving family needs: Extended-day programs in public and private schools. Washington, D.C.: U.S. Department of Education.

U.S. Bureau of Labor Statistics. (2000). Employment characteristics of families: Summary table 4. Washington, D.C.: U.S. Census Bureau.

U.S. Census Bureau. (2000). Urban Institutes Estimates. Washington, D.C.: U.S. Census Bureau.

U.S. Department of Education. (2000). Working for children and families: Safe and smart after-school programs. April. Washington, D.C.: U.S. Department of Justice, U.S. Department of Education.

(c) Copyright of Journal of Youth Development Bridging Research and Practice. Content may not be copied or emailed to multiple sites or posted to a listserv without copyright holder's express written permission. Contact Editor at: patricia.dawson@oregonstate.edu for details. However, users may print, download or email articles for individual use.

ISSN 2325-4009 (Print); ISSN 2325-4017 (Online) 